\title{
Critical evaluation of seismic activities in Africa and curtailment policies - a review
}

\author{
Kenneth Kanayo Alaneme* ${ }^{*}$ and Eloho Anita Okotete
}

\begin{abstract}
The present paper discusses the seismicity of Africa and the need for the implementation of vibration control strategies in Africa, erroneously considered as aseismic. The review catalogues information on the seismicity of Africa, attesting that virtually every region in the African continent has come under the threat of some form of seismic event. The magnitudes and intensities of these seismic activities has resulted in devastations, including: loss of lives, building and civil structures collapse, displacements of people, economic losses, psychological traumatization, and grave fear. Evidences available show that most of the devastations are accentuated by tremor induced collapse of buildings and civil structures. It is thus imperative for substantive, simply implementable, and sustainable proactive measures for controlling the threats of seismic events be discussed within the African context. Current mitigation strategies in Africa include the establishment of seismic codes which govern the design of civil structures. The challenge to the implementation and the effectiveness of the existing African seismic codes was briefly discussed, and new measures which can reduce seismic risks were also highlighted The submissions of the paper is envisaged will create awareness on the budding seismic activities in Africa and awaken relevant authorities on the need for timely and practicable mitigation strategies to be in place to avert the attendant catastrophes associated with seismic occurrences.
\end{abstract}

Keywords: Seismicity, Structural design, Civil structures, Mitigation strategies, Africa

\section{Introduction}

It is a common knowledge among earth scientists that different parts of the world experience varying intensities of seismic related activities and natural disasters. The intensities of these events which include volcanic eruptions, landslides, earthquakes and tsunamis depend on the geophysical and geological features of the region where they occur (Akpan et al. 2015). Tectonic activities occurring beneath the earth's surface are the major causative factors of these events resulting in disturbances which have devastating effects on the earth surface (Elnashai and Sarno 2008). Aside these natural factors, man's activities such as mining, deep quarrying, hydro-geological extraction or fluid disposal and other underground operations have also been known to trigger quakes and other seismic events in some parts of the world (Farahani 2014), which are referred to as induced seismicity. The occurrence of seismic events, regardless its source of manifestation, have

\footnotetext{
* Correspondence: kalanemek@yahoo.co.uk

Department of Metallurgical and Materials Engineering, Federal University of Technology, Akure PMB 704, Nigeria
}

had devastating effects on human lives (the quality of living) and technological advancement in the world.

Earthquake is one major disaster that has had catastrophic consequences in the world today. It has been reported that about 40 disastrous earthquakes have occurred in the world since the end of the twentieth century, and these events claimed an estimated 1.7 million lives (Guo 2010). Earthquakes mostly occur in the oceans, and when the quakes occur in large magnitudes, it results in tsunamis which have led to mass destruction of lives and properties all over the world. What are referred to as continental earthquakes are also prevalent: these are earthquakes which occur on land within the earth's crust and at boundaries of continental plates and active blocks, usually having relatively lower magnitudes than those occurring in the ocean (Elnashai and Sarno 2008). Earthquake events (land or sea) occur suddenly without prior warning; hence responses to earthquake events are often delayed, chaotic, unplanned, and unscientific, thus resulting in even greater loss (Guo 2010; Shelly 2010). The consequences of earthquakes are long-lasting social, environmental, and 
economic problems. It is therefore imperative to improve the means and methods of responses to seismic events to curb the extent of damage per event. Most importantly, there is a great need to improve mitigation strategies to reduce the impacts of earthquakes and other seismic activities on structures. This would save lives and reduce the amount of economic loss incurred during such events.

The African continent though not always associated with seismic events, is currently considered as a seismic prone region. This is because of the rising magnitude and intensities of seismic activities in the continent within the past century. For the technical experts and well informed, it is an issue of grave concern and imperatively requiring awareness and proactive measures to improve the means and methods of responses to curb the extent of its devastations. For the ill-informed or superstitious, it could be viewed as a "malady" of the big nations/ non-African countries. The arbitration of nature to "create a balance" between the well-organized advanced nations with prosperous economies and poor African nations characterized with a history of poor governance and deadly health epidemics. Thus when seismic events happen within some African communities, non-scientific, superstition-laden root causes may be advanced as reason for the occurrence. Worrisome also is the tendency for proffered solutions to follow similar lines of thought. No matter how they are construed, the fact remains that these events have had terrible effect on the citizens and economies of the affected African nations, and consequently it has become necessary for greater awareness of the seismicity of Africa to be brought to the fore.

This review intends to provide detailed evidence of the reality of seismic activities in Africa; highlight some of the underlying factors responsible for their occurrence; report the level of intervention by various governments to address the issues of seismic activities in their domain; and recommend pro-active, cost effective and technically implementable structural design schemes which could be applied within Africa to reduce the effects of earthquakes and other seismic activities in the continent. The intention is to boost awareness of seismic activities in Africa, using a language that even non-technical experts can easily comprehend, as from hindsight, such people are better positioned in Africa than earth science experts to influence government commitment and policies to issues related to seismic threats and curtailment. Presently, there are sparsely available comprehensive literatures on the seismicity of Africa which matches the ambition and scope of the present review paper.

\section{Terminologies in earthquake engineering}

There are different terms used in earth sciences to describe the nature of earthquake and the level of impact of such quakes. These terms facilitate ease of understanding of the event by technical and non-technical experts. Two frequently used terms in seismic studies, are magnitude and intensity.

\section{Magnitude}

This is a quantitative measure which is used to compare the size of earthquakes worldwide irrespective of geographical and geological settings. The magnitude of an earthquake is therefore the logarithmic measurement of the amount of energy released by an earthquake (Hammed et al. 2016). This parameter was established to provide a basis for engineering and geophysical analysis of earthquakes (Kanamori 1983). Richter scale was the foremost approach introduced for assessing the size of earthquakes and laid the foundation for development of earthquake magnitude. This was derived from maximum amplitudes recorded at different epicentral distances from the point of rupture within the earth crust (Richter 1935). The Richter magnitude also known as local magnitude $\mathrm{ML}$, is thus a number characteristic of the earthquake, and independent of the location of the recording station. Later, body-wave magnitude $(\mathrm{mB})$, was introduced to address the inadequacies of ML. $\mathrm{mB}$ is computed from the amplitude and the period of seismic body and its main advantage is the applicability for both shallow and deep seismic events (Kanamori 1983). Body wave magnitude is denoted by $\mathrm{mB}$ for long period body wave magnitude and $\mathrm{mb}$ for short period body wave magnitudes (Liu et al. 2007). Another magnitude for shallow and distant earthquakes, is surface wave magnitude Ms. Moment magnitude scale $\left(M_{\mathrm{w}}\right)$, is a relatively new scale which has the advantage of being used for measurement of larger earthquakes, unlike the Richter amplitude based scales (Baruah et al. 2012).

\section{Intensity}

The effect of an earthquake on the Earth's surface is called the intensity. It is a qualitative measure of the actual shaking at a location during an earthquake, and is assigned with Roman Capital Numerals (Hammed et al. 2016). Intensity scales were originally developed to extract observation data from an earthquake event. The first record scale is the Rossi-Forel scale which used ten degrees to describe earthquake effects in a place (Musson et al. 2010). The intensity scale consists of a series of certain key responses such as people awakening, movement of furniture, damage to chimneys, and finally--total destruction. There were several intensity scales after the Rossi-Forel scale but the Mercalli scale in its fuller version was the most adopted in the early nineties. After several revisions the Mercalli scale became the Modified Mercalli Intensity (MMI)scale which is of prominence among earth scientist today. Table 1 
Table 1 Modified Mercalli Intensity Scale (Adapted from Eiby 1966)

\begin{tabular}{|c|c|}
\hline Level & Description \\
\hline | & $\begin{array}{l}\text { Not felt except by a very few under especially } \\
\text { favorable conditions. }\end{array}$ \\
\hline$\|$ & $\begin{array}{l}\text { Felt only by a few persons at rest, especially on } \\
\text { upper floors of buildings. Delicately suspended } \\
\text { objects may swing. }\end{array}$ \\
\hline III & $\begin{array}{l}\text { Felt quite noticeably by persons indoors, especially } \\
\text { on upper floors of buildings. Many people do not } \\
\text { recognize it as an earthquake. Standing motor cars } \\
\text { may rock slightly. Vibration similar to the passing } \\
\text { of a truck. Duration estimated }\end{array}$ \\
\hline IV & $\begin{array}{l}\text { Felt indoors by many, outdoors by few during the } \\
\text { day. At night, some awakened. Dishes, windows, } \\
\text { doors disturbed; walls make cracking sound. } \\
\text { Sensation like heavy truck striking building. Standing } \\
\text { motor cars rocked noticeably }\end{array}$ \\
\hline V & $\begin{array}{l}\text { Felt by nearly everyone; many awakened. Some dishes, } \\
\text { windows broken. Unstable objects overturned. } \\
\text { Pendulum clocks may stop. }\end{array}$ \\
\hline VI & $\begin{array}{l}\text { Felt by all, many frightened. Some heavy furniture } \\
\text { moved; a few instances of fallen plaster. Damage slight. }\end{array}$ \\
\hline VII & $\begin{array}{l}\text { Damage negligible in buildings of good design and } \\
\text { construction; slight to moderate in well-built ordinary } \\
\text { structures; considerable damage in poorly built or } \\
\text { badly designed structures; some chimneys broken. }\end{array}$ \\
\hline VIII & $\begin{array}{l}\text { Damage slight in specially designed structures; } \\
\text { considerable damage in ordinary substantial buildings } \\
\text { with partial collapse. Damage great in poorly built } \\
\text { structures. Fall of chmineys, factory stacks, columns, } \\
\text { monuments, walls. Heavy furniture overturned. }\end{array}$ \\
\hline IX & $\begin{array}{l}\text { Damage considerable in specially designed structures; } \\
\text { well-designed frame structures thrown out of plumb. } \\
\text { Damage great in substantial buildings, with partial collapse. } \\
\text { Buildings shifted off foundations. }\end{array}$ \\
\hline$X$ & $\begin{array}{l}\text { Some well-built wooden structures destroyed; most masonry } \\
\text { and frame structures destroyed with foundations. Rail bent. }\end{array}$ \\
\hline XI & $\begin{array}{l}\text { Few, if any (masonry) structures remain standing. Bridges } \\
\text { destroyed. Rails bent greatly. }\end{array}$ \\
\hline XII & $\begin{array}{l}\text { Damage total. Lines of sight and level are distorted. Objects } \\
\text { thrown into the air. }\end{array}$ \\
\hline
\end{tabular}

presents an abbreviated description of the 12 levels of Modified Mercalli intensity (Eiby 1966). Other scales which have been adopted in some parts of the world after the MMI scale is Medvedev Sponheuer Karnik (MSK) scale and the modified version for buildings in Europe, European Macroseismic Scale (EMS) (Grünthal 1998; Musson et al. 2010).

The knowledge of and acquaintance with these terminologies, would be found useful in understanding the seismic reports of different regions in Africa.

\section{Seismic activities in Africa}

Seismicity is a term used to describe the frequency of occurrence and intensities (magnitude and seismic moment) of earthquakes in a region (Papazachos 1990).
Seismicity can also be used to express the proneness of a region to earthquake occurrence (historical past and expected future) (Rao and Rao 2004). Seismic activities are often linked to tectonic activities (the movement of continental and oceanic plates) within the earth crust. Earthquakes are typically caused by the movement of the earth crusts leading to the sudden release of energy in the earth's crust, which creates seismic waves that result in ground motion (Doocy et al. 2013). Earthquake forces are generated by the inertia of buildings as they dynamically respond to ground motion (Hamada 2014). According to the U.S. Geological Survey (2016), there are thousands of earthquakes worldwide each year with most going undetected and only a few causing significant property damage, injuries and loss of life. In the recent decade (2007-2017), an estimated 351,839 people have died as a result of earthquakes across the universe.

The seismicity of Africa is considered moderate by world standards (Brandt 2011), however the devastating effect of seismic occurrences in the continent has propelled studies into postulating underlying causes of these events. In Africa, seismic activities differ from region to region, while some regions are still considered as aseismic (void of seismic activities), others have recorded catastrophic seismic events. Seismic events in seismic prone regions in Africa are often linked to tectonic activities in these regions which affect the structure of the earth crust causing disturbances on the surface of the earth. The most prominent tectonic feature in the continent is the East African rift system (EARS), which is one of the world's classical examples of continental rift on land (Kebede and Kulhaneck 1991; Ring 2014). A rift is a belt or zone of a continental lithosphere where there is occurrence of extensional deformation. The rift system in the eastern part of Africa is the bedrock of most of the seismic activities in Africa especially in the northern, eastern and southern parts of the continent. It extends from the Afar triangle (Red Sea and Gulf of Aden), through north Africa (Ethiopia) to southern Africa (Mozambique)(Wafula 2011). The EARS consists of two main branches; the Eastern branch and the Western branch (also known as Western Rift Valley of Africa) (Nyblade and Brazier 2002; Wafula 2011). The eastern branch of the EARS is a volcanic-rich system located north and east of Lake Victoria which extends over $2200 \mathrm{~km}$ southward from the Red Sea, and forms the Kenya and Ethiopian Rifts (Morley et al. 1999; Furman et al. 2004; Chorowicz 2005). On the other hand, the western branch is associated with less volcanism, extending a distance of $2100 \mathrm{~km}$, from Lake Albert (Mobutu) in the north, through to Lake Malawi (Nyasa) in the south. It is composed of other lakes like; Lake Edward (Idi Amin), Lake Kivu basins, Lake Tanganyika and Lake Rukwa (Morley et al. 1999; Chorowicz 2005). Studies have reported that regions along the rifts in 
the EARS system are prone to seismic disturbances which arise from weak zones in the rift. These weak zones are as a result of lithospheric stretching and traction of lithosphere-asthenosphere boundary which leads to thinning and weakening of the earth's crust (Ring 2014). The weak zones also called continental rift zones are also characterized with magnetic anomaly bands, high heat flow and volcanism (Milanovsky 1972). Figure 1 is a sectional map of Africa showing a distribution of earthquake epicentres (source of quake; regions of rupture within the earth crust). It is observed that a large distribution of epicentres is within eastern and northern Africa towards the red sea.

\section{North Africa}

The North Africa region, from Egypt to Morocco, experienced several damaging earthquakes in the past. The largest recorded seismic event reached Mw 7.3 in 1980 at El Asnam in the Tell Atlas of Algeria (Meghraoui et al. 2014). The occurrences of these events in the northern region was linked to its location along the AfricaEurasia plate boundary.

Several earth tremors have been reported in northern Egypt before the 1990s. These earthquake activities which had local magnitudes less than or equal to 5 , were linked with little or no deleterious effect to lives and structures in their region of occurrence throughout the country. This record was however broken when an earthquake with magnitude $\mathrm{mb}=5.9, \mathrm{Ms} .=5.2$ and $\mathrm{ML}$ $=5.3$ shocked Dahshour, Greater Cairo area in October 1992 (Badawi and Mourad 1994). This earthquake resulted in human casualties exceeding 500 persons and this caused severe damage to structures (domestic settlements and historical monuments) near the epicentre (the point of rupture on the earth's surface) which was quite alarming for quakes of average magnitudes (El-Sayed et al. 1998; Khalil et al. 2015).

Other recorded earthquakes in Northern Africa include the 2006 event which occurred in southeast Beni-Suef, Northern Egypt. The earthquake with local magnitude of 4.1 was felt around Beni-Suef and in nearby cities, as far as Cairo which was $160 \mathrm{Km}$ from the epicentre. Although there was no loss of life reported, four other ground vibrations (aftershocks) followed the main event in Beni-Suef in the same month (Badawy et al. 2008).

The Gulf of Suez in northeastern part of Egypt has been reported to experience seismicity of low to intermediate magnitudes (Toni et al. 2016). Higher activities of earthquake were majorly reported around the southern part of the Gulf of Suez, attributed to triple junction and relative plate movements of the Arabian plate, African plate and Sinai-sub plate (Hussein et al. 2006; Morsy et al. 2011). The most recent earthquakes in The Gulf of
Suez are a 4.6 magnitude quake which occurred in the southern part of the region in 2012; and two other earthquakes of magnitudes 4.1 and 5.1 which were reported to have occurred at the central part of the region (the Gulf of Suez) in January and June 2013, respectively (Toni et al. 2016).

Algeria, is another country in the north African region known to experience series of seismic activities. A relatively recent occurrence, was an earthquake of 6.8 magnitude recorded in Bourmedes region of Central Algeria in 2003 (Samai et al. 2017). The shock was felt in Algiers and the neighboring wilayas of Tizi-Ouzou, Bouira, Blida and as far as the Mediterranean Spanish coast where tsunamis of $1-3 \mathrm{~m}$ in amplitude were generated (Bouhadad et al. 2004). The earthquake which was considered the worst in history of the country, claimed 2271 human lives, injured more than 10,000 and hundreds of people are still lost. Also, about 20,000 housing units were destroyed and 160,000 people rendered homeless (Bouhadad et al. 2004). Table 2 is a summary of seismic occurrences recorded in North Africa region in the text.

The Table shows that in the past 15 years, there has been seismic occurrence five times in the north Africa region, four of which occurred in Egypt.

\section{Central Africa}

Seismic activities have been reported in the eastern provinces of the Democratic Republic of Congo (DRC) over the last few decades. These activities ranging from landslides to earthquakes with magnitude greater than 6 have led to loss of lives, properties and stagnant /retarding development in the affected regions (Moeyersons et al. 2004). Bukavu, is one town on the south coast of Lake Kivu in the Democratic Republic of the Congo, which suffers from slow but never-ending landslides. These unfortunate disasters, make life unbearable for inhabitants of such regions, and are often attributed to human factors such as over population and other man-made interactions with the environments, which introduce great instability to the earth crust (Mavonga et al. 2010). However, the peculiar tectonic features associated with the Western rift valley of Africa have been reported as the primary cause of earthquake and other seismic activities in Bukavu town and other cities in the same region (Mavonga and Durrheim 2009; Mavonga et al. 2010). Aside landslides, earthquake of Mw 6.2 and 6.0 occurred in the Lake Kivu region in 2002 and 2008(Mavonga 2007; Mavonga et al. 2010). The 6.0 Mw quake of 2008 was majorly felt in the north of Bukavu city, and recorded lot of casualties including the death of 9 people, and serious injuries to more than 400 people (Mavonga et al. 2010). The event also led to the collapse of about 1500 houses rendering many of the inhabitants homeless. Early predictions which involve the 


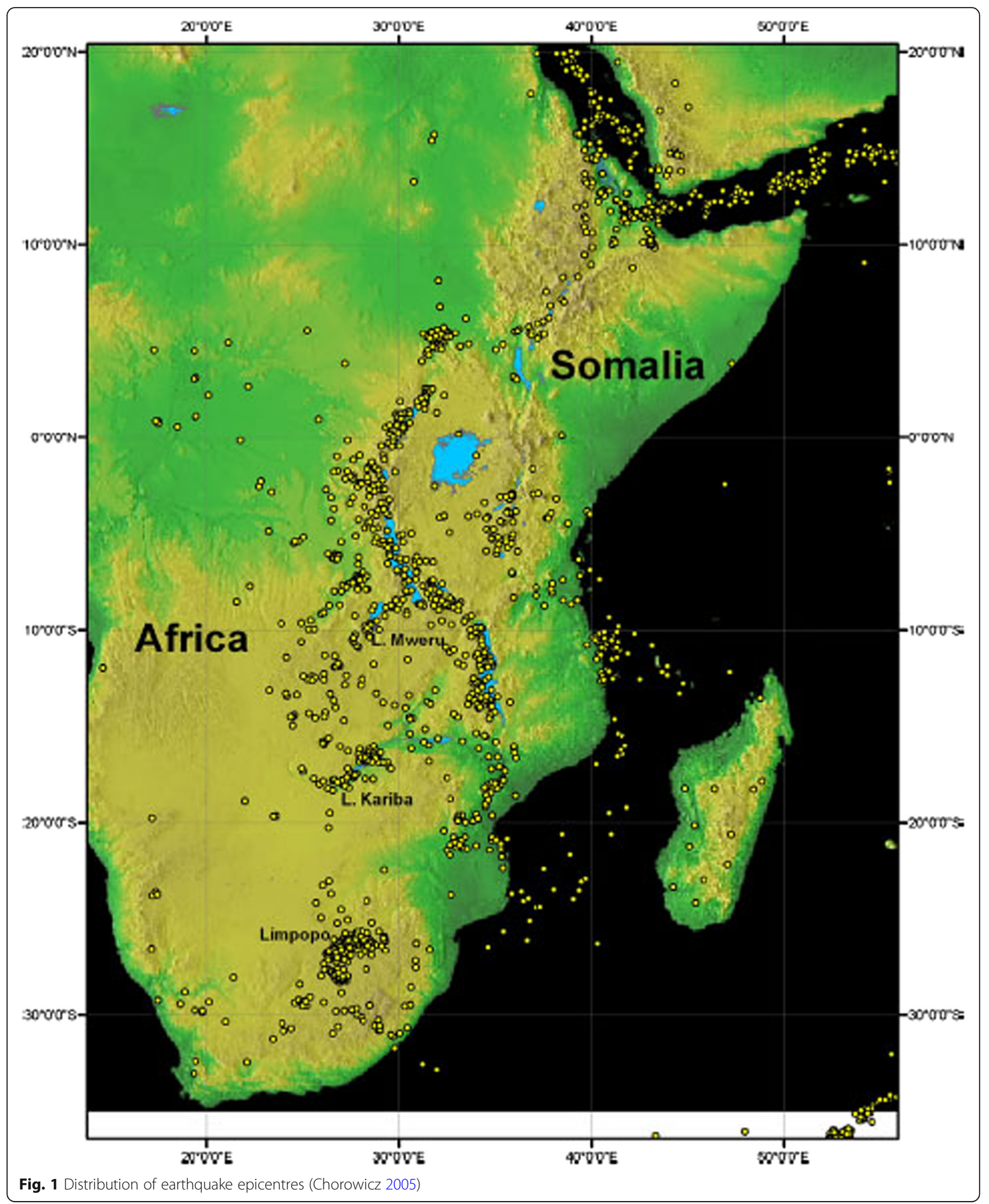


Table 2 Seismic occurrences, location, year, magnitude and intensity in North Africa

\begin{tabular}{|c|c|c|c|c|c|c|}
\hline$S / N$ & Year & Country & Town/Area Felt & Seismic activity & Intensity & Magnitude \\
\hline 1 & 1970 & Algeria & El-Ansam & Earthquake & - & 7.3 \\
\hline 2. & 1992 & Egypt & Dahsour,Cairo & Earthquake & - & $5.3(\mathrm{ML}), 5.9(\mathrm{mb}), 5.2(\mathrm{MS}$ \\
\hline 3. & 2003 & Algeria & Bourmedes & Earthquake & - & 6.8 \\
\hline 4. & 2006 & Egypt & Beni-Suef & Earthquake & - & 4.1 \\
\hline 5. & 2012 & Egypt & The Gulf of Suez & Earthquake & - & 4.6 \\
\hline 6. & 2013 & Egypt & The Gulf of Suez & Earthquake & - & 4.1 \\
\hline 7. & 2013 & Egypt & The Gulf of Suez & Earthquake & - & 5.1 \\
\hline
\end{tabular}

use of local seismic velocity model to relocate hypocenters of earthquakes is one means which have been suggested by Mavonga et al. (2010) to mitigate the earthquake riskin DRC.

Earthquakes of different magnitudes have also been reported in Cameroon. The city of Kribi, in the southern province of Cameroon experienced a 3.6 magnitude earthquake in 2002, which caused severe ground vibrations across the city. This led to a lot of distress, anxiety and panic amongst the population (Nfomou et al. 2004); there were however no records of casualties after the event. Another earthquake with no recorded catastrophe was reported in the central province of Cameroon in 2005. The quake which had a magnitude of 3.1, was felt as far as Yaounde, the capital city of Cameroon, about $81 \mathrm{Km}$ from the source (Ndikum et al. 2014). Aside earthquakes, Cameroon has also recorded a number of other natural disasters such as landslides and floods which displaced citizens of the affected areas from their residence for a period of time. A summary of some the seismic occurrences in central Africa is presented in Table 3. It is observed that the four recorded seismic activities were within the past 18 years, the last of which occurred 10 years ago.

\section{East Africa}

Uganda has been reported to be very prone to earthquake because it is situated between two seismically active branches of the East African rift system. The vulnerability of several parts of the country to earthquake is further accentuated by the low quality of structures, and increase in urbanization and industrialization into the earthquake prone areas (Twesigomwe 1997). The quakes which have occurred in the history of Uganda have had devastating effect on lives and structures in the country. Therefore, efforts are being made to provide early predictions to seismic activites in the country (Nyago 2017). The United States geological survey recently recorded a 5.3 magnitude earthquake in south western Uganda. The event which occurred in July, 2017 recorded no injuries, deaths or damages to structures, but residents in the region were forced to flee their houses during the tremors (Dispatch 2017).

In 2016, an earthquake with local magnitude of 5.9 on the Richter scale hit the Lake Victoria region between Tanzania, Uganda and Rwanda. The epicenter for the earthquake was to the east of the north-western town of Nsunga on the border of Lake Victoria. The earthquake was considered 7.99 (VIII) on the Modified Mercalli Intensity scale which is between very strong and severe, signifying slight damage in well-built structures and extensive/considerable damage in poorly designed structures (Manyele 2016). The event which struck very close to Bukoba in Tanzania, generated ground acceleration and wreaked extensive damage to buildings in Bukoba, resulting in 17 fatalities, 252 injured people and 840 families left homeless. In Uganda, the strong ground motion induced by the Lake Victoria earthquake, killed four people in Kamuli and seven others were injured in the Rakai District. The quake also caused panic and fear in Rwanda, Burundi, and Kenya (All Africa.com, The Observer 2016).

Earthquake with magnitudes between 5 and 7 have been often reported in Eritrea in the 1900's. In 1993, an earthquake swarm of magnitude 5.2 was observed in Bada, Eritrea and this was accompanied with rock slides, wide spread faulting, and related surface manifestations. The event was however not associated with damaging

Table 3 Seismic occurrences, location, year, magnitude and intensity in Central Africa

\begin{tabular}{|c|c|c|c|c|c|c|}
\hline $\mathrm{S} / \mathrm{N}$ & Year & Country & Town/Area Felt & Seismic activity & Intensity & Magnitude \\
\hline 1. & 2002 & Democratic Republic of congo & Lake Kivu region & Earthquake & - & $6.2(\mathrm{Mw})$ \\
\hline 2. & 2002 & Cameroon & Kribi region & Earthquake & - & 3.6 \\
\hline 3. & 2005 & Cameroon & Central City/ Yaounde & Earthquake & & 3.1 \\
\hline 4. & 2008 & Democratic Republic of congo & Lake Kivu region (Bukavu City) & Earthquake & - & $6.0(\mathrm{Mw})$ \\
\hline
\end{tabular}


consequences (Ogubazghi et al. 2004). The Bada area is prone to seismic activities because it is situated in a major rift system where it is said that the African and Arabian plates are moving away from each other. In addition, the occurrence of earthquake swarm in the Bada area is attributed to volcanic activities which weaken the earth crust (thickness between 10 and 15 $\mathrm{km})$ (Ogubazghi et al. 2004).

An earthquake of 4.4 body-wave magnitude has also been recently reported in the Hawassa region of Ethiopia. Tremors from the quake which occurred in January, 2016 was felt in almost all the cities and towns in the region, but no major injuries were reported as a direct consequence of the earthquake. A series of further tremors were also reported to cause minor structural damage in Hawassa as well as scattered power outages all over the region. This event made some residents to become apprehensive of returning to their homes and rather chose to sleep outside in fear of building collapse (Wilks et al. 2016). A summary of some seismic events (those recorded in the text) which have occurred in the eastern region of Africa is presented in Table 4. Four countries within the region are observed to have experienced seismic activities in the past 2 years (2016-2018), after the last which occurred in 1993 in Eritrea.

\section{Southern Africa}

The East African rift extends to the Southern African region; it is therefore expected that this region will be prone to seismic activities. On the contrary, the south of Africa has only recorded moderate seismicity over the years; majority of which are mining-related seismicity, triggered by deep rooted mining activites which cause instability within the earth (Alabi et al. 2013). Most of earthquakes reported in the region have therefore been earthquakes of small local magnitude between 2 and 5 (Mangongolo et al. 2017).

The September 29th, 1969 earthquake which occurred in Ceres-Tulbagh region of western Cape province, South Africa, is one of the strongest ever recorded seismic event in South Africa (Krüger and Scherbaum 2014). The event which recorded 6.2 on the moment magnitude scale $(\mathrm{Mw})$ was felt throughout the southern part of South Africa, as far north as Upington in the Northern Cape Province, and as far east as Durban in the KwaZulu-Natal Province (Midzi et al. 2013). Series of aftershocks were recorded after the quake, the strongest had a magnitude of $5.7(\mathrm{Mw})$ and occurred on 14 April 1970. The 1969 earthquake caused severe damages to buildings in the towns of Tulbagh, Wolsely, Ceres and Prince Alfred Hamlet; several casualties were reported and nine lives were lost (Kijko et al. 2002). Total damages to building in the epicentral area was estimated at US $\$ 24,000,000$.

An unexpected quake of high magnitude and intensity occurred about a decade ago in Mozambique. The event which had the highest magnitude in Africa since the early nineteen hundred, occurred in February, 2006. The earthquake had a magnitude of 7 and had series of aftershocks from February till April 2006, which had magnitudes between 5.1 and 5.8 (Yang and Chen 2008). The unusually high magnitude of the earthquake was surprising, since the faulting mechanism which caused the quake typically results in seismic events of lower magnitudes, thus it was opined that other factors could have contributed to the high magnitude of the quake (Linzer et al. 2007).

A small earthquake of 4.3 body-wave magnitude was also recorded in Nyamandlovu area, near Bulawayo city in Zimbabwe in 2008. Although, this quake was felt in the entire Bulawayo city which was home to over a million people, the event recorded no injuries to residence of the city or structures (Shumba et al. 2009). Table 5 presents a record of some of the seismic activities in the southern Africa region.

\section{West Africa}

In the west African sub-region, seismic activities have been reported majorly in Nigeria, Ghana, and Sierra Leone (2017). In Ghana, sparse earthquake events occurred within the sixteen hundreds down to nineteen hundred, despite being situated in the southeastern margin of the West Africa craton which is far away from the major earthquake zones (active plate boundaries) (Amponsah 2002; Amponsah et al. 2012). Earthquakes were recorded in the southern part of Ghana where the Akwapim fault intersected the coastal boundary fault and the epicentres of the earthquake were related to the level of fault activities in these regions (Amponsah 2002). The most eventful seismic activity ever recorded in Ghana was the 6.8 magnitude earthquake which occurred in June, 1939 (Amponsah 2002; Allotey et al.

Table 4 Seismic occurrences, location, year, magnitude and intensity in East Africa

\begin{tabular}{lllllll}
\hline S/N & Year & Country & Town/Area Felt & Seismic activity & Intensity & Magnitude \\
\hline 1 & 1993 & Eritrea & Bada & Earthquake & - & 5.2 \\
2. & 2016 & Ethiopia & Hawassa & Earthquake & - & 4.4 \\
3. & 2016 & Tanzania, Uganda, Rwanda & Bukoba, Kawuli, Rakai & Earthquake & 7.99 & 5.9 \\
4. & 2017 & Uganda & South western Uganda & Earthquake & - & 5.3 \\
\hline
\end{tabular}


Table 5 Seismic occurrences, location, year, magnitude and intensity in Southern Africa

\begin{tabular}{|c|c|c|c|c|c|c|}
\hline$S / N$ & Year & Country & Town/Area Felt & Seismic activity & Intensity & Magnitude \\
\hline 1, & 1969 & South Africa & Ceres-Tulbagh & Earthquake & - & $6.2(\mathrm{Mw})$ \\
\hline 2. & 1970 & South Africa & Ceres-Tulbagh & Earthquake- Aftershock & - & $5.7(\mathrm{Mw})$ \\
\hline 3. & 2006 & Mozambique & South of Lake Malawi & Earthquake & - & 7 Aftershocks-5.1 and 5.8 \\
\hline 2. & 2008 & Zimbabwe & Bulawayo & Earthquake & - & $4.3(\mathrm{mb})$ \\
\hline
\end{tabular}

2010). The 1939 quake caused a lot of casualties and recorded an intensity of IX on the modified mercalli intensity scale (Amponsah 2002). In 1997, series of earth tremors struck Ghana and was felt around the regional capitals of the country (Allotey et al. 2010).

Sierra Leone (2017) has never been known as a country which experiences seismic activites, but slight tremors were felt in Freetown when a 7.1 magnitude earthquake hit the Atlantic Ocean in 2016.

\section{Seismic activities in Nigeria}

Nigeria and other countries located along the mobile belt of Africa between West African craton and Congo craton are believed to be aseismic (without earthquake or other seismic activities). However, Nigeria began experiencing series of earthquakes of low local magnitudes (between 4 and 5) from the early 1930s, and this led to in depth studies into the seismology of the country (Tsalha et al. 2015). Some studies have reported that earthquakes in Nigeria are triggered by intraplate tremors unlike what occurs in other regions of Africa (Eze et al. 2012). This tremor was attributed to regional stresses created as a result of the country's position between the West Africa craton and Congo craton, and zones of weakness resulting from magmatic intrusions and other tectonic activities in the sediments (Eze et al. 2012; Afegbua et al. 2011). Most of the early earth quakes in Nigeria were not well documented because of the absence of seismology equipment at those times. Table 6 presents a list of historical earthquakes and tremors felt in Nigeria and the regions with documented scientific measures; and also other earthquake events which were not documented scientifically.

One of the most recent earthquake event in Nigeria is the quake of 2009 which was felt in Abeokuta, Ago-Iwoye, Ajambata, Ajegunle, Imeko, Ijebu-Ode, Ilaro and Ibadan towns of south western Nigeria. The earthquake which had a local magnitude of 4.4 was reported to be triggered by a ruptured fault within the upper crust (Akpan et al. 2014).

In 2016, series of earth tremors and quakes were felt in Saki, Oyo state in south western Nigeria, also in communities in Bayelsa and Rivers State in Southern Nigeria, and Jabal area of Kaduna state in North western Nigeria (Vanguard.com 2017). The most recent occurred in September 2018 in the countries capital city, Abuja
(Premium Times.com 2018). The causes of these events are presently uncertain and studies on the events are still ongoing, a clear indicator that Nigeria may not be free of earth tremors in the near future.

The review on the seismicity of Africa has shown that Africa is not only prone to seismic activities but the frequency of the occurrences has been on the rise at the turn of the century due to changing tectonic activities and increased human interaction with the earth surface. It is thus imperative for proactive measures to be instituted to avert any potential adverse consequences of seismic activities that may arise in future.

\section{Mitigation strategies for structural vibration- African record}

Reports from the previous section have shown that Africa is prone to seismic activities of varying magnitudes especially the regions around the EARS. These seismic activities have caused serious damage to properties, reduced the quality of living and even led to instabilities in economies of some of the affected nations. The intensity of seismic events is often measured on the Modified Mercalli Intensity (MMI) scale which provides information on the observed effects of the event (extent of vibration) on people (and other living things), objects and buildings /infrastructures around the region of occurrence (Midzi et al. 2013). The information on the scale maybe subjective to accounts of residents in the area where the event took place, but it gives a guide on the extent of damage and shock per event. Studies have shown that the intensity of earthquakes in Africa vary between I and VIII, signifying that earthquakes around the African continent range from minimal or no effect to slight damages on well-designed buildings. Although the damages have not been very severe, it is necessary to devise earthquake mitigating methods, since the continent is known to undergo intra-plate earthquakes which increase the frequency of earthquake occurrences on the surface of the earth.

Most earthquake deaths are reported to be related to partial or complete collapse of civil structures (Kenny 2009). These deaths are linked to the response of the structural and non-structural parts of building to ground vibrations during earthquakes. Arya, (2000) divided earthquake protection measures for buildings into three major parts which are; based on architectural design, 
Table 6 List of Historical Earth Tremors in Nigeria (Adapted from Akpan and Yakubu 2010 and Eze et al. 2012)

\begin{tabular}{|c|c|c|c|c|c|}
\hline $\mathrm{S} / \mathrm{N}$ & Year & Felt Areas (Towns) & Intensity & Magnitude & Probable Epicenter \\
\hline \multicolumn{6}{|l|}{ A } \\
\hline 1. & 1939 & Lagos, Ibadan and Ile-Ife & - & $6.5(\mathrm{Mr}), 5.3(\mathrm{Ms})$ & Akwapim fault in Ghana \\
\hline 2. & 1963 & ljebu-Ode & V & - & Close to ljebu-Ode \\
\hline 3. & 1982 & Jalingo and Gembu & III & - & Close to Cameroon volcanic line \\
\hline 4. & 1984 & $\begin{array}{l}\text { ljebu-Ode, Shagamu, Ibadan, } \\
\text { Abeokuta and ljebu Remo }\end{array}$ & $\mathrm{V}-\mathrm{Vl}$ & - & Close to ljebu-Ode \\
\hline 5. & 1985 & Kombani Yahya & IV & - & Kombani Yahya \\
\hline 6. & 1990 & Ibadan & - & $3.7(\mathrm{ML})$ & Close to ljebu-Ode \\
\hline 7. & 1994 & - & & $4.2(\mathrm{ML})$ & Dan Gulbi \\
\hline 8. & 1997 & Okitipupa & IV & - & Close to Okitipupa \\
\hline \multirow[t]{2}{*}{9.} & 2000 & $\begin{array}{l}\text { Ibadan, Akure, Abeokuta, ljebu-Ode } \\
\text { and Oyo }\end{array}$ & - & 4.5 (Mb), 3.9 (Ms) & Close to Okitipupa \\
\hline & & Akure & IV & - & Close to Okitipupa \\
\hline 10. & 2005 & Yola & III & - & - \\
\hline 11. & 2006 & Lupma & III & - & Close to Cameroon volcanic line \\
\hline 12. & 2009 & $\begin{array}{l}\text { Abeokuta, Ago-Iwoye, Ajambata, } \\
\text { Ajegunle, Imeko, Ijebu-Ode, Ilaro } \\
\text { and Ibadan }\end{array}$ & & $4.4(\mathrm{ML})$ & - \\
\hline \multicolumn{6}{|l|}{ B } \\
\hline 1. & 1933 & Warri & - & - & - \\
\hline 2. & 1961 & Ohafia & - & - & - \\
\hline 3. & 1975 & Dambata & - & - & - \\
\hline 4. & 1981 & Kundunu & - & - & - \\
\hline 5. & 1984 & Yola & - & - & Close to Cameroon volcanic line \\
\hline 6. & 1986 & Obi & - & - & - \\
\hline 7. & 1987 & Akko, Gembe and Kurba & - & - & - \\
\hline 8. & 2000 & Jushi-Kwari & & & \\
\hline 9 & 2016 & Saki & - & - & - \\
\hline 10 & 2016 & Bayelsa, Rivers & - & - & - \\
\hline 11 & 2016 & Jabal & - & - & - \\
\hline 12 & 2018 & Abuja & - & - & - \\
\hline
\end{tabular}

Where, ML is local magnitude (Richter magnitude), Ms is surface-wave magnitude, Mb is body-wave magnitude, and Mr is magnitude used in Richter (not popularly used)

structural counter measures, and construction and maintenance quality. However, studies around the world have been channelled towards the advancement of structural designs which would minimize the adverse effects of earthquakes on buildings which could eventually reduce the casualties associated with such seismic events. Effective methodologies for building design against earthquake should consider the dynamic response of the building to forces generated by earthquakes. This can be achieved by selection of the preferred response mode, selecting zones where inelastic deformations are acceptable and suppressing the development of undesirable response modes which could lead to building collapse (Constantinou and Symans 1993).
The inherent strength of a building is one major parameter that affects its response to seismic events. Different buildings have different responses to seismic excitations. Adobe buildings and other non-engineered building are low cost buildings which are very popular in developing nations (countries in Africa). These buildings which are made from materials which have low compressive strength and stiffness are mostly patronized because of their low cost and simplicity of construction, and excellent thermal and acoustic properties (De Risi et al. 2011). Arya (2000) surmised that most non-engineering buildings lack good permanence under seismic action, and are therefore prone to partial or full collapse when subjected to earthquakes of relatively high 
intensities (between VII and IX). Unfortunately, these buildings are still erected in rural regions of some parts of Africa.

\section{The African record}

In recent years, urban areas of most countries in Africa are surrounded with reinforced concrete structures as an improvement to non-engineered structures (Adobe, mud) which are susceptible to damages from harsh climatic conditions and seismic activities. Studies have however shown that these reinforced concrete buildings do not show total resistance to ground vibrations during earthquakes (Bourahla et al. 2008). In the Africa continent, most of the recent earthquakes have been reported to cause risks to the citizens ranging from slight to moderate damages to buildings, and this have resulted in temporary/permanent displacements (Manyele 2016). This implies that a great deal of effort is required to improve the seismic response of reinforced concrete buildings in parts of the continent which have shown considerable susceptibility to seismic activities. Efforts have been made by some governments of African countries to publish regulations which would ultimately minimize the impact of the risks associated with seismic activities. Some of these regulations/policies are discussed in the succeeding section.

\section{North Africa}

As discussed earlier, Egypt is considered as a country with low to moderate seismicity. There was no official regulation in Eygpt to address the seismic tendency of the country until 1989 when the government published the first official code of practice which consider seismic loading of buildings (ECP-1989) (Raheem 2013). After the 1992 Cairo earthquake, it was realized that the code overlooked many seismic consideration, including: the influence of site conditions and dynamic characteristics of buildings under seismic load (Abdel-Raheem et al. 2010). Consequently, a revised seismic code was issued on December 1993 (ECP-1993) to provide a means for determining the optimum/required seismic loads for different types of structures in seismic zones in the country (Raheem 2013). An updated version of the Egyptian code was published in 2003 (ECP-2003) which marked the adoption of response spectra and codified force reduction factors for the design of structures in seismic zones. The ECP-2003 seismic code takes into consideration the effect soil parameter on response spectra of buildings (El-Arab 2011; Raheem 2013). The Egyptian code ECP201, 2008 makes provision for ductility concepts and detailing procedures for the adoption of these concepts in design of buildings in seismic zones (Serror et al. 2010; El-Arab 2011; Raheem 2013). The most recent version of the Egyptian code was developed in 2011. Despite the efforts made by the government of Egypt to introduce seismic code, Badawy et al. (2016) stated that if an earthquake of similar magnitude to the 1992 Cairo event was to occur in the near future the damages and economic losses consequent on its occurrence would be higher than what was recorded in 1992. The study proposed measures which could be adopted to reduce the earthquake risks of similar magnitude as the 1992 Cairo event. The proposed measures include risk reduction through technical inspection of buildings and facilities to address requirements for seismic retrofitting and increasing the efficiency/ resistance of structures in seismic zones to extensive damages. Building codes, standards, and practices for earthquake hazards must also be constantly re-evaluated in light of the goal for sustainable mitigation. The authors summarily proposed a five-step road map for risk reduction, and to improve the seismic performance of structures and assure life safety and collapse prevention in future earthquakes. These are (1) upgrade of the exiting constructions with suitable retrofit, (2) rebuilding better structures, (3) regular maintenance of structures, (4) suitable site selection for new structures, and (5) public awareness and outreach to residence on how to behave pre, during, and post-earthquakes.

The nature of damages and fatalities experienced during the Boumerdes earthquake (2003) ordinarily should not be associated with a nation such as Algeria which have well established seismic regulations. Seismic regulations were first established in Algeria after the severe Earthquake of El Asnam October 10, 1980 (magnitude 7.3). Algerian Seismic Regulation 81 (RPA81) was the first regulation established to reduce the impact of earthquakes on buildings and other infrastructure (Zermout et al. 2014). Over the years, the RPA 81 has undergone several revisions like RPA 83, 88 and 99. The RPA99 regulation has recently been revised to a newer version RPA99/Version 2003 (CGS, 2003) in response to the May 2003 Zemmouri earthquake (Zermout et al. 2014). This is a clear indication that seismic regulations have been in existence prior to the 2003 earthquake, yet catastrophic failure of structures was reported all around Boumerdes. This implies that the existing code was not implemented and enforced for control of construction in seismic prone regions in Algiers and other regions of Algeria. It is therefore imperative for the government of Algeria to seek out policies which would ensure enforcement of the existing regulations to prevent future risk in the event of earthquakes. One strategy which has been suggested by Bendimerad (2004) to prevent future extensive damages and chaos during earthquakes and other similar disasters is the simplification of the existing seismic code for easy adaption for single-family buildings. Also, the enlightenment of citizens on the importance of adhering to seismic code for design and construction of structures, and stringent enforcement of seismic codes 
for all civil structures would reduce the economic and human losses usually recorded during earthquakes. Bendimerad (2004) similarly suggested that retrofitting of already existing vulnerable buildings in seismic prone regions could be considered a long term approach to reduce the losses associated with disasters in the major cities in Algeria. Meslem et al. (2012) stated in a post-earthquake investigation that the alarming extent of damages recorded in the Boumerdes 2003 event was attributed to the presence of non-engineered private buildings in the Boumerdes area. Since the existing Algerian seismic code at that time were only applied to public buildings. The report from the investigation also mentioned site condition as another factor which contributed to the severe damages recorded in buildings during the earthquake; and should be taken into consideration to prevent future destruction of similar nature. The findings in the report were drawn from the observation that buildings erected on flat planes recorded slight damages compared to similar buildings erected on steep slopes and small hilltops. The authors therefore advised that site condition also be a key factor to consider when revising the seismic code for buildings in Algeria.

\section{Central Africa}

This part of Africa and west Africa have recorded the least earthquake occurrences till date. There are no documented evidence of deliberate policies or regulations to address the rising earth tremors, landslides, floods and other disasters.

\section{East Africa}

East Africa is one of the first regions to be considered seismic in Africa, and this was because of the occurrence of earthquakes with high magnitude and intensities. It has been established from geological studies that the seismicity of this region (Eastern Africa) is linked to its situation along the East African rift system. The active seismicity of this region therefore instigated early efforts to establish seismic codes for design of buildings and other civil structures. Kenya seismic code was one of the first seismic code to be established in East Africa and in the whole of Africa as a continent (Worku 2014). Worku (2014) reported that the Kenyan seismic code was reported to be established in 1973, and the code used the Modified Mercalli Intensity (MMI) scale to map out region of seismic hazards in the country. Unfortunately, this code has not been revised since that year (1973) and may not be a reliable measure to reduce the risk associated with earthquakes in event of their future occurrence. This is because the structures which are currently being erected in Kenya in the present day are not the same used for establishment of the seismic code, and the changing nature of geological activities beneath the earth's crust would affect the extent and nature of ground shaking/vibrations during future events (earthquakes).

In Uganda, the vulnerability of civil structures to damages during earthquakes and other natural disasters is ameliorated using the Ugandan seismic code. The seismic code of Uganda uses US-319 for seismic design and the current version US 319:2003 was issued by the Ugandan National Bureau of Standards in 2003 (Worku 2014; Zajac and Davis 2015). This code is used to assess the ductility of a structural system (building or other civil constructions) by taking into cognisance the seismic zone factor (seismicity of the region from the seismic zone map), structural importance factor and structural performance factor (type of structural system and materials).

Earthquakes have been a regular occurrence in Ethiopia due to its location on the major tectonic plates (the African and Arabian plates) in the world. These earthquakes of varying magnitudes and intensities have had devastating effects on civil structures at the different seismic zones of the country. In response to the extensive seismic activities in Ethiopia, the Ethiopian seismic code was established in 1980 to reduce the risks associated with earthquakes. The code (CP1-78) used numbers 1-4 to rank seismic regions, and each zone was assigned a danger rating with 'no', 'min', 'moderate', and 'major' (Kinde et al. 2011). The Ethiopian code was subsequently revised in 1983 (ESCP1-83), this was to address the aseismic design of structural members not included in the previous code (Kinde et al. 2011; Worku 2014). The current version is the Ethiopian Building Code Standard, EBCS 8: 1995. This code dedicates a separate volume for seismic provisions for design and construction of buildings in seismic regions, and was revised based on newer records of earthquakes in Ethiopia and other nearby countries (Kinde et al. 2011; Worku 2011). In 2013, a committee was formed and entrusted to update the code for a third time (Lubkowski et al. 2014). The efforts of the Ethiopian government to reduce earthquake risk by constantly reviewing the seismic code for design of civil structure is commendable. However, Kinde et al. (2011) reported that the enforcement of the code by the legal system of the country was not instituted until 2009. Furthermore, Kinde et al. (2011) proposed that the code which is under revision should consider site specific zoning to reduce risks to building during earthquakes. The authors also suggested that the revised code should have a use of return-period (validity period) of 475 years as against the 100 years in previous codes which is considered not conservative enough for buildings, and should include special concrete and steel seismic provision. The possibility of establishing specialized codes for large infrastructures such as dams, power-plants, railway structures and 
bridges was also proposed by the authors. Kassegne (2014) have also suggested that newer data, a difference in the earthquake return period and the consideration of local site conditions could account for some of the differences observed in seismic zoning data reported by researchers over the last 30 years. The author therefore highlighted the need for new seismic code to address this issue, while also suggesting the implementation of more stringent torsional requirements in the revised Ethiopian seismic building code. In another study, Worku (2013) noted that modern seismic design codes in the developed world have become more demanding in terms of incorporating requirements related to design forces and deformations of buildings in those codes. Thus, the revision of African seismic codes is paramount at a time such as this. Worku (2013) proposed that the adaptation of soil-structure interaction (SSI) in some international codes into local African codes, would substantially reduce the base shear force of structures so that the sizes of structural elements would also be proportionally less. This would reduce the overall construction costs of buildings erected according to this new conditions in the revised codes.

\section{Southern Africa}

Studies have shown that South Africa has only moderate seismic activities which are mainly man-made as a result of mining and other underground activities which cause instability in earth's crust. The south African loading code (SABS 0160 (1989)) was the first seismic regulation/code to be published in south Africa. Although subjected to some revisions in 1993, this code was the first standard used to identify regions in the country (south Africa) where building structures had to be designed for seismic loading (Wium 2010). This code was established to reduce the seismic risk of south Africa and other southern African nations. However, it was observed that majority of civil engineers and architects were either unaware of the existence of the code or failed to implement the code for economic or technical (opted for international codes) reasons (Wium 2010). These issues together with inadequacies observed in the code propelled a revision of the existing code. The first major revision to the south African code was SANS 10160 (2009), and this code was established to provide the basic principles of conceptual layout for acceptable behaviour of structures under seismic loads (Wium 2010). The code placed emphasis on structural simplicity, uniformity of buildings in plan layout and elevation, and on structural redundancy. Other revisions to the south African seismic code include (SANS 10160:2010) (Worku 2014) which was published to allow structures in seismic zones to dissipate energy by nonlinear material behaviour during major seismic events. The revised code allows a building to be designed incorporating a behaviour factor which depends on the material type and structural system to reflect energy dissipation under seismic loading (Retief and Wium 2012; Roth and Gebremeskel 2017). The original SANS 10160-4:2010 has since been amended to SANS 10160-4:2011(Roth and Gebremeskel 2017).

\section{West Africa}

The record of past seismic activities led to the institution of The Ghanaian Code - 1990. The latest Ghanaian seismic code is the one established for the Seismic Design of Concrete Structures issued in 2010 by the Ghanaian Building and Road Research Institute. The current code for Ghana which accommodates seismic loading in building design divided the country into three different seismic zone, and assigns a peak rock surface acceleration to each zone (Worku 2014). However, this code was based on the singular deterministic approach presented on a hazard map in recent seismic study in Amponsah et al. (2009). In Nigeria, the only standard that exists for the construction of buildings do not take into consideration the dynamic response of buildings to seismic loading (Ogunbiyi 2014).

This section has shown that although Africa was considered as aseismic many years ago, most governments in several regions of Africa have established regulations which will guide the design of buildings and other infrastructures in the event of earthquakes or other natural disasters. This is proof that there is a degree of awareness of the seismic risks in the continent and efforts have been made to curb these risks. However, there are some lapses noted to cut across most regions from the reports presented in this section. First, the existing codes in most of the countries in the African continent do no exhaustively address all the issues associated with response of structures in the event of ground vibrations. Issues like site conditions were not addressed in some of these codes and regulations. The inadequacies of some of the existing seismic regulations could be attributed to the fact that most of the seismic regulations (seismic codes) were modified from building codes (construction practices for civil structures). Thus, lack due consideration of peculiar existing seismic features of each region. Also, another limitation that was observed to hinder the mitigation of earthquake risks in most African countries is the lack of implementation /enforcement of existing seismic codes. Most of the existing codes are not currently used in the countries where they are available. The reason for this is uncertain, but could be attributed to lack of policies to enforce these codes. Table 7 presents a review of codes and standards available for design of buildings in African countries. 


\section{Recommended remediation strategies for the African setting}

Poor seismic response of buildings and civil structures is the major contributing factor for the extensive casualties, damages and destructions associated with earthquakes and other seismic occurrences (Bilham 2009; Fernandez 2014). Hence, contemporary studies have been geared towards improving the dynamic response of building when under the influence of sudden external loads which arise in the event of earthquakes and other seismic events. In Africa, there is substantial evidence of mitigation strategies to reduce earthquake risks in form of codes and regulations which have been established by governments of countries prone to seismic activities. However, there are several records of economic losses and human losses in earthquake events despite the existence of these regulations. This suggests that the existing regulations are not effective for the purpose of reducing earthquake risks. It is thus expedient to investigate the reason for the ineffectiveness of these regulations.

Several works have linked the ineffectiveness of the existing African seismic codes to different reasons. The ineffectiveness of African codes has been attributed to the lack of legal policies to enforce existing codes, which gives room for the erection of buildings with poor design in seismic zones (Kinde et al. 2011; Worku 2014). Also, the ineffectiveness of seismic codes in the African continent for earthquake risk curtailment has been linked to the establishment of codes with narrower scope limited to government owned structures like hospital, schools and other public structures (Bendimerad 2004; Meslem et al. 2012). Similarly, existing African codes are observed to be deficient in specific seismic features peculiar to different seismic zones, and this definitely affects the response of civil structures during earthquake events (Worku 2013; Kassegne 2014). This is demonstrated in the use of substandard and inadequate seismic hazard assessment approaches in hazard estimation. Therefore, there is a pressing need to reiterate the existing earthquake mitigation strategies, and suggest new strategies that could be deployed for the African setting.

The earth scientists, architects, civil engineers and governments in Africa countries should be applauded for efforts made to publish good seismic codes in response to the rising seismicity in various parts of the continent. There is hardly any seismic region in Africa which does not have codes/regulations that governs the

Table 7 Seismic Code and Standards in African Countries which are prone to seismic activities

\begin{tabular}{|c|c|c|c|}
\hline $\mathrm{S} / \mathrm{N}$ & Country & Code/Standard & Seismic Code? \\
\hline 1 & Egypt & $\begin{array}{l}\text { Egyptian Code } 201 \text { 2008-draft (ECP201, 2008-draft) } \\
\text { (Serror et al. 2010) }\end{array}$ & Yes \\
\hline 2 & Algeria & RPA99/Nersion 2003 (CGS, 2003) (Zermout et al., 2008) & Yes \\
\hline 3 & Cameroon & None & No \\
\hline 4 & Democratic Republic of Congo & None Exists & No \\
\hline 5 & Ethiopia & $\begin{array}{l}\text { Ethiopia Building Code Standard (EBCS) 1995, Volume } \\
8 \text { Seismic. (Lubkowski et al. 2014) }\end{array}$ & Yes \\
\hline 6 & South Sudan & No code exists & No \\
\hline 7 & Uganda & $\begin{array}{l}\text { US 319:2003,Ugandan Ministry of Lands, Housing and } \\
\text { Urban (Zajac and Davies, 2015) }\end{array}$ & Yes \\
\hline 8 & Rwanda & $\begin{array}{l}\text { Building Regulations Manual (2009) from the Rwanda } \\
\text { Ministry of Infrastructure (MININFRA). (Lubkowski et al. 2014) }\end{array}$ & Yes \\
\hline 9 & Burundi & Not Known & No \\
\hline 10 & Kenya & Kenyan Code (1973) (Worku 2014) & Yes \\
\hline 11 & Tanzania & Not known. & No \\
\hline 12 & Malawi & $\begin{array}{l}\text { Various Malawi Standards including for building materials } \\
\text { and construction practices. (Lubkowski et al. 2014) }\end{array}$ & No \\
\hline 13 & Djibouti & Not known. & No \\
\hline 14 & Mozambique & $\begin{array}{l}\text { A version of the Portuguese Code from the colonial era } \\
\text { (Bommer 2010). }\end{array}$ & No \\
\hline 15 & South Africa & $\begin{array}{l}\text { The South African Code - SANS 10160-4:2011 (Roth and } \\
\text { Gebremeskel 2017) }\end{array}$ & No \\
\hline 16 & Ghana & The Ghanaian Code - 1990 (Worku 2014) & Yes \\
\hline 17 & Nigeria & Nigeria National Building Code (NBC, 2006) (Ogunbiyi 2014) & No \\
\hline 18 & Sierra Leone & Not Known & No \\
\hline
\end{tabular}


erection of civil structures in seismic zones. This supports the assertion that the well-informed are taking proactive measure to reduce earth risk in Africa. However, earthquake risk reduction would only be possible when both the well-informed, ill-informed, and unscrupulous adhere strictly to the existing seismic codes. Bilham (2009) stated that corruption and ignorance are two major factors which currently circumvents the best efforts to reduce earthquake risks in civil structure in some developing nations. The technical experts and governments should therefore make conscious efforts to first of all educate the masses on the growing seismicity of the African region and the role of these seismic regulations in curbing the effects. The success of this awareness program would subsequently pave way for adherence to legal policies which would ensure execution of the existing codes for building design.

Apart from a few reports (Saunders et al. 2008), there are very few documentations of seismic monitoring and instrumentation networks in countries across the regions of Africa where seismic events have been reported. It is recommended that the governments of these countries set up monitoring systems to adequately prepare and mitigate the associated risk of seismic events.

Also, the enactment of laws and policies which would guide blasting operations, civil engineering constructions that produces high frequency vibrations, and groundwater extraction activities is also expedient for regions where seismicity is as a result of anthropogenic activities. These policies would reduce earthquake and other seismic risk thereby eliminating the need to design expensive civil structures which would be earthquake resistant.

It has also been reported that increased urbanization is partially responsible for some of the seismic events in Africa. Rapid urbanization has increased the population of big cities and also increased the number of structures per location in some cities in African countries. These factors significantly increases the extent of damages in the event of earthquakes. Furthermore, urbanization and industrialization have placed huge demand on available resources, leading to increase exposure to natural and induced disasters (underground operations which triggers earthquakes by causing instability in the earth's crust). Institution of policies which would discourage urbanization, and promote the conservation of natural resources, can help reduce the number of induced seismic events and reduce the number of casualties and economic losses per event.

Another major factor which has hampered earthquake risk reduction is the cost of designing structures in accordance with existing seismic codes. Most owners of private buildings do not adhere to seismic codes for economic reasons, and prefer to erect either non-engineered buildings or buildings with low engineering cost. A study was conducted by De Risi et al. (2011) to improve the seismic resistance of non-engineered buildings in Italy, using two simple and low-cost retrofit strategies: the use of chains (increasing out-of-plane resistance) and reinforced mortar jacketing (increasing in-plane stiffness). The study demonstrated that adopting these simple techniques leads to significant improvement in the over-all performance of the structure in terms of strength and stiffness.

Super structures and high rise buildings are a contemporary trend in big cities in most African countries. The structures are more prone to dynamic motions compared to lower buildings and hence it is good to address their response to seismic loads in the African setting. The use of passive vibration control systems can be used to control responses of these buildings by incorporating materials which have good energy dissipation capabilities in their design. The energy dissipation devices/components/materials would absorb the external energy supplied to the structure during seismic loading thereby improving their responses to such loadings. Many engineering materials have been used in the design of energy dissipating devices in passive vibration control systems in civil structures (Housner et al. 1997; Symans and Constantinou 1999; Spencer and Nagarajaiah 2003). Shape memory alloys fall into the category of such materials, and $\mathrm{Cu}$ and $\mathrm{Fe}$ based shape memory alloys are cheaply processed alloys which have been well reported to be reliable in improving seismic responses of buildings and civil structures (Song et al. 2006; Torra et al. 2007; Lee et al. 2013).

The authors recognise that seismicity of the different regions of Africa is not sufficient to make recommendations on possible mitigation strategies for earthquake prone regions. However, the review was targeted at enlightening the average citizen of the existing/blooming seismic threats, the success achieved so far, and the way forward to reduce earthquake risks.

\section{Conclusion}

This review has illuminated the often trivialized seismicity of Africa with a view to advocate the need for the implementation of vibration control strategies in Africa. The review has shown that virtually every region in the African continent has come under the threat of some form of seismic event with magnitudes and intensities resulting in a wide range of devastations. Since documented evidences show that most of the devastations are accentuated by tremor induced collapse of buildings and civil structures; the review considers it imperative for proactive measures to be implemented. Such measures it advances ought to be pragmatic, sustainable and cost-effective for it to be successful in Africa. It was recorded that most regions which have experienced seismic activities over the last three decades have seismic 
codes which were published to mitigate seismic risks. The challenge to the implementation and effectiveness of the existing African seismic codes was observed to be lack of legal policies to enforce published codes, narrow scope of available codes and rigid revision practices in some countries. The review has also highlighted new measures to reduce earthquake and seismic risks in African countries. This is envisioned will curb the threats imminent from seismic activities which are becoming prevalent in Africa.

\section{Abbreviations}

EMS: European Macroseismic Scale; $M$ w: Moment magnitude scale; mB: Body-wave magnitude; ML: Richter magnitude also known as local magnitude; MMI: Modified Mercalli Intensity; Mr: Magnitude used in Richter; Ms: Surface wave magnitude; MSK: Medvedev Sponheuer Karnik

\section{Acknowledgements}

Not Applicable.

\section{Funding}

Not Applicable.

\section{Availability of data and materials} Not Applicable.

\section{Authors' contributions}

The lead author conceptualized the review work, the template for the review, literature sourcing, drafting of the manuscript, editorial and structure review, finalization of corrections. The second author contributed to literature sourcing, drafting of the manuscript, editorial and structure review. Both authors read and approved the final manuscript.

\section{Authors' information}

Not Applicable.

\section{Competing interests}

The authors declare that they have no competing interests.

\section{Publisher's Note}

Springer Nature remains neutral with regard to jurisdictional claims in published maps and institutional affiliations.

\section{Received: 18 September 2018 Accepted: 26 November 2018}

Published online: 20 December 2018

\section{References}

Abdel-Raheem, K.A., S.E. Abdel Raheem, H.M. Soghair, and M.H. Ahmed. 2010. Evaluation of seismic performance of multistory buildings designed according to Egyptian code. Journal of Engineering Sciences, Assiut University 38 (2): $381-402$

Afegbua, K.U., T.A. Yakubu, O.U. Akpan, D. Duncan, and E.S. Usifoh. 2011. Towards an integrated seismic hazard monitoring in Nigeria using geophysical and geodetic techniques. International Journal of the Physical Sciences 6 (28): 6385-6393.

Akpan, E., A.O. Ilori, and N.U. Essien. 2015. Geophysical investigation of Obot Ekpo landslide site, Cross River state, Nigeria. Journal of African Earth Sciences 109: 154-167.

Akpan, O.U., M.A. Isogun, T.A. Yakubu, A.A. Adepelumi, C.S. Okereke, A.S. Oniku, and M.I. Oden. 2014. An evaluation of the 11th September, 2009 earthquake and its implication for understanding the Seismotectonics of South Western Nigeria. Open Journal of Geology 4 (10): 542-550.

Akpan, O.U., and T.A. Yakubu. 2010. A review of earthquake occurrences and observations in Nigeria. Earthquake Science (3): 289-294.

Alabi, A.A., O.D. Akinyemi, and A. Adewale. 2013. Seismicity pattern in southern Africa from 1986 to 2009. Earth Science Research 2 (2): 1-10.

All Africa.com, The Observer. 2016: Lives lost, houses collapse as earthquake hits Uganda. Retrieved 2017-11-10.
Allotey, N.K, G. Arku, and P.E. Amponsah. 2010. Earthquake-disaster preparedness: the case of Accra. International Journal of Disaster Resilience in the Built Environment 1 (2): 140-156.

Amponsah, P., G. Leydecker, and R. Muff. 2012. Earthquake catalogue of Ghana for the time period 1615-2003 with special reference to the tectono-structural evolution of south-East Ghana. Journal of African Earth Sciences 75: 1-13.

Amponsah, P.E. 2002. Seismic activity in relation to fault systems in southern Ghan. Journal of African Earth Sciences 35: 227-234.

Amponsah PE, Banoeng-Yakubo BK, Panza GF, Vaccari F. Deterministic seismic ground motion modeling of the greater Accra metropolitan area, southeastern Ghana. South African Journal of Geology, 2009;112:317-328.

Arya, A. 2000. Non-engineered construction in developing countries-an approach toward earthquake risk prediction. In Proceedings of 12th WCEE, 2824.

Badawi, H.S., and S.A. Mourad. 1994. Observations from the 12 October 1992 Dahshour earthquake in Egypt. Natural Hazards 10: 261-274.

Badawy, A., A.K. Abdel-Fattah, S.M. Ali, and W. Farid. 2008. Source parameters of the ML 4.1 earthquake of November 08, 2006, southeast Beni-Suef, northern Egypt. Journal of African Earth Sciences 51: 151-159.

Badawy, A., I. Korrat, M. El-Hadidy, and H. Gaber. 2016. Update earthquake risk assessment in Cairo, Egypt. Journal of Seismology. https://doi.org/10.1007/ s10950-016-9621-5.

Baruah, S., S. Baruah, A. Kalita, R. Biswas, N. Gogoi, J.L. Gautam, M. Sanoujam, and J.R. Kayal. 2012. Moment magnitude - local magnitude relationship for the earthquakes of the Shillong-Mikir plateau, northeastern India region: a new perspective. Geomatics, Natural Hazards and Risk 3 (4): 365-375.

Bendimerad F. The 21 May 2003 Boumerdes earthquake lessons learned and recommendations, 13th World Conference on Earthquake Engineering. Vancouver (2004) Paper No. 9001.

Bilham, R. 2009. The seismic future of cities. Bull Earthquake Enginerring 7: 839-887.

Bouhadad, Y., A. Nour, A. Slimani, N. Laouami, and D. Belhai. 2004. The Boumerdes (Algeria) earthquake of May 21, 2003 (Mw = 6.8): ground deformation and intensity. Journal of Seismology 8: 497-506.

Bourahla N, Tafraout S, Bouriche F. 2008 The algerian seismic code and perspectives of the african code. RPA 99-2001 | Earthquake Engineering | Earthquakes Scribd, https://www.scribd.com/document/64841286/RPA-99-2001

Brandt, M. 2011. Seismic Hazard in South Africa. Council for Geoscience Report 0061: 1-22.

Chorowicz, J. 2005. The East African rift system. Journal of African Earth Sciences 43: $379-410$.

Constantinou, M.C., and M.D. Symans. 1993. Seismic response of structures with supplemental damping. The Structural Design of Tall Buildings 2: 77-92.

De Risi, R., F. Jalayer, I. lervolino, and G. Manfredi. 2011. Seismic performance assessment and upgrade design of a generic Adobe building. ANIDIS BARI.

Dispatch 2017, (Uganda's News monthly, 2017-07-30), 5.3 magnitude earthquake strikes southwestern Uganda, Retrieved 2017-11-01.

Doocy, S., A. Daniels, C. Packer, A. Dick, and T.D. Kirsch. 2013. The Human Impact of Earthquakes: a Historical Review of Events 1980-2009 and Systematic Literature Review. Plos Current Disasters 1: 1.

Eiby, G.A. 1966. The modified Mercalli scale of earthquake intensity and its use in New Zealand. New Zealand Journal of Geology and Geophysics 9 (1-2): 122-129.

El-Arab, I.E. 2011. Seismic analysis of existing school buildings using different Egyptian seismic provisions. Procedia Engineering: The Twelfth East Asia-Pacific Conference on Structural Engineering and Construction 14: 1906-1912.

Elnashai, A.S., and L.D. Sarno. 2008. Fundamentals of earthquake engineering.

El-Sayed, A., R. Arvidsson, and O. Kulh'anek. 1998. The 1992 Cairo earthquake: a case study of a small destructive event. Journal of Seismology 2: 293-302.

Eze, C.L., V.N. Sunday, S.A. Ugwu, E.D. Uko, and S.A. Ngah. 2012. Mechanical model for Nigerian intraplate earth tremors. Advances in Science and Technology 6(2): $80-84$.

Farahani, J.V. 2014. Man-made major hazards like earthquake or explosion; case study, Turkish mine explosion (13 may 2014). Iranian Journal of Public Health 43 (10): 444-1450.

Fernandez, F. 2014. Strategies to Reduce the Risk of Building Collapse in Developing Countries, PhD Thesis (Dissertations.) Paper 493. Pittsburgh: Carnegie Mellon University.

Furman, T., J.G. Bryce, J. Karson, and A. lotti. 2004. East African rift system (EARS) plume structure: Insights from quaternary mafic lavas of Turkana, Kenya. Journal of Petrology 45 (5): 1069-1088.

Grünthal G (ed) European Macroseismic Scale 1998. Cahiers du Centre Europèen de Gèodynamique et de Seismologie. Conseil de l'Europe, Conseil de l'Europe (1998). 
Guo, H. 2010. Understanding global natural disasters and the role of earth observation. International Journal of Digital Earth 3 (3): 221-230.

Hamada, M. 2014. Earthquake-resistant design and reinforcement. In Engineering for earthquake disaster mitigation, springer series in geomechanics and geoengineering. https://doi.org/10.1007/978-4-431-54892-8_2.

Hammed, O.S., M.O. Awoyemi, G.O. Badmus, and O.O. Sanni. 2016. Interdepedence and variations of earthquake parameters on African lithospheric plate using Gutenberg and Richter relations. Journal of Geography, Environment and Earth Science International 4 (4): 1-12.

Housner, G.W., L.A. Bergman, T.K. Caughey, A.G. Chassiakos, R.O. Claus, S.F. Masri, R.E. Skelton, T.T. Soong, B.F. Spencer, and J.T.P. Yao. 1997. Structural control: Past, present, and future. Journal of Engineering Mechanic 123 (9): 897-971.

Hussein, H.M., I. Marzouk, A.R. Moustafa, and N. Hurukawa. 2006. Preliminary seismicity and focal mechanisms in the southern gulf of Suez: August 1994 through december 1997. Journal of African Earth Sciences 45: 48-60.

Kanamori, H. 1983. Magnitude scale and quantification of earthquakes. Tectonophysics 93: 185-199.

Kassegne, S.K. 2014. Proposed Considerations for Revision of EBCS-8:1995 for Conservative Seismic Zoning and Stringent Requirements for Torsionally Irregular Buildings.

Kebede, F., and O. Kulhaneck. 1991. Recent seismicity of the east African rift system and its implications. Physics of the Earth and Planetary Interiors 68: 259-273.

Kenny, C. 2009. Why do people die in earthquakes? The costs, benefits and institutions of disaster risk reduction in developing countries. The World Bank Sustainable Development Network Finance Economics \& Urban Department, Policy Research Working Paper 4823, 1-40.

Khalil, A.E., A. Deif, and H.E. Abdel Hafiez. 2015. Seismic Hazard assessments at Islamic Cairo, Egypt. Journal of African Earth Sciences 112: 287-298. https:// doi.org/10.1016/j.jafrearsci.2015.09.008

Kijko, A., S.J.P. Retief, and G. Graham. 2002. Seismic hazard and risk assessment for Tulbagh, South Africa: Part I - Assessmaent of seismic Hazard. Natural Hazards 26: 175-201.

Kinde, S., S. Engeda, A. Kebede, and E. Tessema. 2011. Notes and proposed guidelines on updated seismic codes in Ethiopia implication for large-scale infrastructures. Journal of EEA 28: 91-110.

Krüger, F., and F. Scherbaum. 2014. Short note: the 29 September 1969, Ceres, South Africa, earthquake: full waveform moment tensor inversion for point source and kinematic source parameters. Bulletin of the Seismological Society of America 104 (1): 1-6. https://doi.org/10.1785/0120130209.

Lee, W.J., B. Weber, G. Feltrin, C. Czaderski, M. Motavalli, and C. Leinenbach. 2013. Stress recovery behaviour of an Fe-Mn-Si-Cr-Ni-VC shape memory alloy used for prestressing. Smart Materials and Structures 22: 125037 (9pp).

Linzer, L.M., M. Bejaichund, A. Cichowicz, R.J. Durrheim, O.D. Goldbach, M.O. Kataka, and J.S. Webb. 2007. Recent research in seismology in South Africa. South African Journal of Science 103: 9-10.

Liu, R., Y. Chen, X. Ren, Z. Xu, L. Sun, H. Yang, J. Liang, and K. Ren. 2007. Comparison between different earthquake magnitudes determined by China seismograph network. Acta Seismologica Sinica 20 (5): 497-506.

Lubkowski, Z., K. Coates, M. Villani, N. Jirouskova, and M. Willis. 2014. Seismic design considerations for East Africa. In Second European Conference on Earthquake, 1-12. Istanbul: Engineering and Seismology.

Mangongolo, A., F.O. Strasser, I. Saunders, and G.W. Rathod. 2017. Depths of earthquakes in South Africa. Seismological Research Letters 88 (4): 1-11.

Manyele, A. 2016. The 10Th September 2016 Lake Victoria earthquake: Insights from distributions of strong ground motion, felt intensity and induced damages. International Journal of Science, Engineering and Technology Research 5 (10): 3009-3014.

Mavonga, T. 2007. Some characteristics of aftershock sequences of major earthquakes from 1994 to 2002 in the Kivu province, Western Rift Valley of Africa. Tectonophysics 439: 1-12.

Mavonga, T., and R.J. Durrheim. 2009. Probabilistic seismic hazard assessment for the democratic republic of Congo and surrounding areas. South African Journal of Geology 112: 329-342.

Mavonga, T., N. Zana, and RJ. Durrheim. 2010. Studies of crustal structure, seismic precursors to volcanic eruptions and earthquake hazard in the eastern provinces of the Democratic Republic of Congo. Journal of African Earth Sciences 58: 623-633.

Meghraoui, M., A. Harbi, and H.M. Hussein. 2014. Preface to the special issue "Seismotectonics and seismic hazards in North Africa". Journal of Seismology 18: 203-204

Meslem, A., F. Yamazaki, Y. Maruyama, D. Benouar, A. Kibboua, and Y. Mehani. 2012. The effects of building characteristics and site conditions on the damage distribution in Boumerde's after the 2003 Algeria earthquake. Earthquake Spectra 28 (1): 185-216.

Midzi, V., J.J. Bommer, F.O. Strasser, P. Albini, B.S. Zulu, K. Prasad, and N.S. Flint. 2013. An intensity database for earthquakes in South Africa from 1912 to 2011. Journal of Seismology. https://doi.org/10.1007/s10950-013-9387-y.

Milanovsky, E.E. 1972. Continental rift zones: their arrangement and development, In: R.W. Girdler (Editor), East African Rifts. Tectonophysics 15 (I/2): 65-70.

Moeyersons, J., P. Tre'fois, J. Lavreau, D. Alimasi, I. Badriyo, B. Mitima, M. Mundala, D.O. Munganga, and L. Nahimana. 2004. A geomorphological assessment of landslide origin at Bukavu, Democratic Republic of the Congo. Engineering Geology 72: 73-87.

Morley, C.K., D.K. Ngenoh, and J.K. Ego. 1999. Introduction to the east African rift system. In Geoscience of rift systems-Evolution of East Africa: AAPG studies in geology no. 44, ed. C.K. Morley, 1-18.

Morsy, M., H.M. Hussein, K.M. Abou Elenean, and Sh. El-Hady. 2011. Stress field in the central and northern parts of the Gulf of Suez area, Egypt from earthquake fault plane solutions. Journal of African Earth Sciences 60: 293-302

Musson, R.M.W., G. Grünthal, and M. Stucchi. 2010. The comparison of macroseismic intensity scales. Journal of Seismology 14: 413-428.

Ndikum, E.N., C.T. Tabod, A.K. Tokam, and B.Z. Essimbi. 2014. Fault-plane solution of the earthquake of 19 march 2005 in Monatele (Cameroon). Open Journal of Geology 4: 289-293.

Nfomou, N., A.F. Tongwa, U.R. Ubangoh, A. Bekoa, N.J. Metuk, and H.J. Victor. 2004. The July 2002 earthquake in the Kribi region: Geological context and a preliminary evaluation of seismic risk in southwestern Cameroon. Journal of African Earth Sciences 40: 163-172.

Nyago J. Seismic observation and seismicity of Uganda, Uganda's Seismological Activities and Earthquake Risk Mitigation, Retrieved 1 Nov 2017. http://iisee. kenken.go.jp/net/shiva/update/Uganda_Joseph_NYAGO_revised2.pdf

Nyblade, A.A., and R.A. Brazier. 2002. Precambrian lithospheric controls on the development of the east African rift system. Geological Society of America 30 (8): 755-758.

Ogubazghi, G., W. Ghebreab, and J. Havskov. 2004. Some features of the 1993 Bada earthquake swarm of southeastern Eritrea. Journal of African Earth Sciences 38: 135-143.

Ogunbiyi, M.A. 2014. The national building code and the construction industry professionals in Nigeria. International Journal of Social Sciences and Entrepreneurship 1 (12): 937-948.

Papazachos, B.C. 1990. Seismicity of the Aegean and surrounding area. Tecronophysics 178: 287-308.

Premium Times.com 2018. https://www.premiumtimesng.com/news/top-news/ 282825-abuja-tremor-not-earthquake-nigerian-govt.html, date. Retrieved: 15 Sept 2018.

Quartz Africa, Sierra Leone's tragic mudslide disaster is a stark reminder of the country's poor urban planning, Retrieved 2017-11-08.

Raheem, S.E.A. 2013. Evaluation of Egyptian code provisions for seismic design of moment-resisting-frame multi-story buildings. International Journal of Advanced Structural Engineering 5 (20): 1-18.

Rao, P.C., and D.B. Rao. 2004. A textbook of geology.

Relief Web, Sierra Leone: Mudslides - Aug 2017, 2017, Retrieved 2017-11-08

Retief, J.V., and J.A. Wium. 2012. Principles and application of structural design code development in South Africa. Structural Engineering International 2: 182-189.

Richter, C. 1935. An instrumental earthquake magnitude scale. Bulletin of the Seismological Society of America 25 (1): 1-31.

Ring, U. 2014. The east African rift system. Austrian Journal of Earth Sciences: An International Journal of the Austrian Geological Society 107 (1): 132-146.

Roth, C.P., and A. Gebremeskel. 2017. Updated provisions of SANS 10160-4 for steel structures. Journal of the South African Institution of Civil Engineering 59 (1): 45-47 Note 75.

Samai, S., M. Idres, M. Ouyed, A. Bourmatte, M.S. Boughacha, M. Bezzeghoud, and J.F. Borges. 2017. A structural scheme proposal derived from geophysical data in the epicentral area of the Boumerdes (Algeria) earthquake of May 21, 2003. Journal of African Earth Sciences. https://doi.org/10.1016/j.jafrearsci.2017.05.018

Saunders, I., M. Brandt, J. Steyn, D. Roblin, and A. Kijko. 2008. The south African National Seismograph Network. Seismological Research Letters 79 (2): 203-210.

Serror, M.H., M.M. Hassan, and S.A. Mourad. 2010. Towards a boundary between special and ordinary steel moment resisting frames in the Egyptian code. In Proceedings of 14th European Conference on Earthquake Engineering, 197. Ohrid.

Shelly, D.R. 2010. Periodic, chaotic, and doubled earthquake recurrence intervals on the deep San Andreas fault. Science 328: 1384-1388. 
Shumba, B.T., D.J. Hlatywayo, and V. Midzi. 2009. Focal mechanism solution of the 15th march 2008, Nyamandlovu earthquake. South African Journal of Geology 112: 381-386.

Song, G., N. Ma, and H.N. Li. 2006. Applications of shape memory alloys in civil structures. Engineering Structures 28: 1266-1274.

Spencer, B.F., and S. Nagarajaiah. 2003. State of the art of structural control. Journal of Structural Engineering 129: 845-856.

Symans, M.D., and M.C. Constantinou. 1999. Semi-active control systems for seismic protection of structures: A state-of-the-art review. Engineering Structures 21: 469-487.

Toni, M., A. Barth, S.M. Ali, and F. Wenzel. 2016. Analysis of the similar epicenter earthquakes on 22 January 2013 and 01 June 2013, central gulf of Suez, Egypt. Journal of African Earth Sciences 121: 274-285.

Torra, V., A. Isalgue, F. Martorell, P. Terriault, and F.C. Lovey. 2007. Built in dampers for family homes via SMA: An ANSYS computation scheme based on mesoscopic and microscopic experimental analyses. Enineering Structures 29: 1889-1902.

Tsalha, M.S., U.A. Lar, T.A. Yakubu, U.A. Kadiri, and D. Duncan. 2015. The review of the historical and recent seismic activity in Nigeria. IOSR Journal of Applied Geology and Geophysics 3 (1): 8-56.

Twesigomwe, E.M. 1997. Seismic hazards in Uganda. Journal of African Earth Sciences 24 (1/2): 183-195.

US Goelogical Survey (2016): "Historic earthquakes and earthquake statistics: what damages are caused by earthquakes?" Retrieved 17 Aug 2017 at http:// earthquake.usgs.gov/ learn/faq/?category|D=11\&faq $\mid \mathrm{D}=95$.

Vanguard.com. Earthquake in Nigeria: measures to avert devastating impacts— experts 2017, Retrieved 2017-10 29.

Wafula, D.M. 2011. Impacts of tectonic earthquake in the western rift valley of Africa on the volcanic activity of Nyirangongo, Virunga region. Asian Journal of Scientific Research 4 (3): 209-223.

Wilks, M., A. Ayele, J.M. Kendall, and J. Wookey. 2016. The 24th January 2016 Hawassa earthquake: Implications for seismic hazard in the Main Ethiopian rift. Journal of African Earth Sciences. https://doi.org/10.1016/j.jafrearsci.2016.11.007.

Wium, J.A. 2010. Background to draft SANS 10160 (2009): Part 4 seismic loading. Journal of the South African Institution of Civil Engineering 52 (1): 20-27 688

Worku, A. 2011. Recent developments in the definition of design earthquake ground motions calling for a revision of the current ethiopian seismic code EBCS 8: 1995. Journal of EEA 28: 1-15.

Worku, A. 2013. Seismic soil-structure interaction as a potential tool for economical seismic design of building structures. Journal of EEA 30: 55-66.

Worku, A. 2014. The status of basic design ground motion provisions in seismic design codes of sub-Saharan African countries-a critical review. Journal of the South African Institution of Civil Engineering 56 (1): 40-53 Paper 977.

Yang, Z., and W. Chen. 2008. Mozambique earthquake sequence of 2006: highangle normal faulting in southern Africa. Journal of Geophysical Research 113 (B12303): 1-8.

Zajac, C., and T. Davis. 2015. A comparative analysis for base shear calculations between six countries with moderate seismic activity. In AEI, 775-787.

Zermout, S., F. Bakhti, Y. Mehani, M. Inukai, T. Azuhata, and T. Saito. 2014. Seismic vulnerability of a strategic building designed by Algerian seismic code RPA 99 , using the capacity Spectrum method, the 14th world conference on earthquake engineering October 12-17, 2008, Beijing, China. Journal of Geology 4: 542-550

\section{Submit your manuscript to a SpringerOpen ${ }^{\circ}$ journal and benefit from:}

- Convenient online submission

- Rigorous peer review

- Open access: articles freely available online

- High visibility within the field

- Retaining the copyright to your article

Submit your next manuscript at $\boldsymbol{\nabla}$ springeropen.com 